Annals of Warsaw University of Life Sciences - SGGW

Land Reclamation No 47 (2), 2015: 103-112

(Ann. Warsaw Univ. Life Sci. - SGGW, Land Reclam. 47 (2), 2015)

\title{
The influence of curing time on the shear strength of fluidized fly ash
}

\author{
ANDRZEJ GRUCHOT \\ Department of Hydraulic Engineering and Geotechnics, University of Agriculture in Cracow
}

\begin{abstract}
The influence of curing time on the shear strength of fluidized fly ash. The paper presents results of research on the influence of compaction and air and water curing on angle of internal friction and cohesion of fluidized fly ash from "Połaniec" Power Plant. It was stated that the increase in compaction resulted in an insignificant increase of the angle of internal friction and a quite significant increase of cohesion. While the type and time of curing had a great influence on the angle of internal friction and cohesion. The highest values of angle of internal friction were obtained in the air curing, and the lowest in the water curing whereas in case of cohesion there was an inverse relation. The rise of curing time resulted in largely increased cohesion and small changes of angle of internal friction.
\end{abstract}

Key words: shear strength, fluidized fly ash, recycling

\section{INTRODUCTION}

An increasing demand for electricity and thermal energy and at the same time decreasing resources of high quality fuels drew greater attention to the technique of fluidized bed combustion and gasification. A peculiar construction of the fluidized-bed furnaces allows combustion of all types of energy materials, such as traditional solid or liquid fuels but also industrial, agricultural or municipal wastes. The energy value of the fuels combusted in the fluidized-bed furnaces has a wide range of values, from 4000 to $36,000 \mathrm{MJ} \cdot \mathrm{kg}^{-1}$ (Hycnar 2006, Niesler 2011). In relation to pulverized coal furnace, fluidized bed combustion in a moderated temperature allows to limit the amount of nitrogen oxide and greatly reduce the emission of sulfur pollutants as a result of limestone addition to the combusted fuels. Therefore using a specific grain fractions of hard and brown coals, petroleum coke, bituminous shale and peat as a fuel, often combusted with the addition of coal slime, biomass or wastes from sewage treatment plants has become relevant also because of the environment protection requirements and economy (Hycnar 2006).

Combustion of such diverse fuels in the fluidized-bed furnaces results in a production of so-called coal combustion by-products (CCBs), whose amount and quality significantly differ from the ones produced in traditional pulverized coal furnaces. A mineralogical, organic and granulometric composition of wastes from fluidized-bed furnaces differs from the composition of traditional fly ash and slag, which determinates the 
possibilities of their usage. The fly ash is mainly used in mining as a component of hydraulic backfill. The fluidized ash contains up to $50 \%$ of clay minerals, which makes it a good material for any type of sealings in an underground mining, as well as in fire protection (Iwanek et al. 2008). The fluidized ash is also added to soils as a fertilizer or during biological remediation. It improves physical properties of the soil, increases $\mathrm{pH}$ and limits mobility of heavy metals, which is crucial during reclamation of degraded lands, for example in Upper Silesia (Bielińska et al. 2009). Fly ashes are also used to improve weak ground (Filipiak 2011, 2013, Koda and Osiński 2011, Gawlicki and Wons 2013).

Fluidized ashes, because of their binding properties, can be a component of cement mixtures (Roszczynialski and Gawlicki 2004). Although these ashes do not fulfill the requirements of a standard (PN-EN 197-1:2012) and cannot be used directly in cement production (Giergiczny 2006). A similar situation is when it comes to using fluidized fly ashes in concrete production (Kabała et al. 2006).

Another form of use of the fluidized ash is a production of binding materials used in stabilization of weak soils e.g. in road engineering. An example of such material is SILMENT, which is produced from cement and fly ash (Zawisza and Kłęk 2006, Zawisza and Gruchot 2008). According to the Regulation of the Minister of Environment from 21 March 2006 on recovery or disposal of waste beyond installations and devices, ashes from traditional furnaces have a wide range of applications and can be used, among other things, as an independent material in embankments or construction layers under the requirements of relevant road standards. However, the possibilities of using ashes from the fluidized-bed furnaces in road constructions are limited because they require detailed tests and development of new technologies of construction (Sybilski and Kraszewski 2004).

Tests on strength parameters of fly ashes are mainly focused on their use in concrete production and therefore on determining their influence on strength parameters of concrete mixtures (Brzozowski 2011, Kubissa et al. 2013) or binding time of self-hardening slurries with the addition of the fluidized ashes (Pomykała et al. 2013). On the other hand strength parameters of the ashes in the aspect of their use in earthworks are examined only to a minor extend. Therefore an attempt to determine strength parameters of chosen fluidized ashes was made in the paper.

\section{MATERIAL AND METHODS}

The aim of the paper was to determine the influence of compaction and curing time (both air and water) on the shear strength parameters, i.e. angle of internal friction and cohesion, of fluidized fly ash from "Połaniec" Power Plant.

Basic physical and compaction parameters were determined using standard 
methods. Grain size distribution was determined using laser diffraction. Specific density tests were carried out using a mensural flask and distilled water. An optimum water content and maximum dry density were determined in Proctor apparatus in a $1.0 \mathrm{dm}^{3}$ cylinder at the compaction energy of $0.59 \mathrm{~J} \cdot \mathrm{cm}^{-3}$.

Shear strength tests were carried out in a direct shear box apparatus in boxes zone dry or immersed in water) and after 0.5 and 16 hours of curing with air and water (Table 1) in the apparatus box. Additionally, tests on samples after 7 days of curing (also with air and water, but outside of the apparatus box) were also carried out. In case of water and air-water curing the samples were sheared while the shearing zone was immersed in water.

TABLE 1. Curing of samples of fluidized fly ash before the shear strength test

\begin{tabular}{|l|l|}
\hline Curing time & \multicolumn{1}{|c|}{ Course of curing samples } \\
\hline 0 & $\begin{array}{l}\text { The testes carried out directly after samples compaction with a shear zone dry or im- } \\
\text { mersed in water }\end{array}$ \\
\hline \multirow{3}{*}{0.5 hour } & $\begin{array}{l}\text { Air: the samples compacted and cured in the apparatus box in a room temperature, } \\
\text { protected from drying }\end{array}$ \\
\cline { 2 - 3 } & $\begin{array}{l}\text { Water: the samples compacted and cured in the apparatus box immersed in water at } \\
\text { its full height }\end{array}$ \\
\hline \multirow{3}{*}{16 hours } & Air: the samples compacted and cured in the apparatus box in a room temperature \\
\cline { 2 - 3 } 7 days & $\begin{array}{l}\text { Water: the samples compacted and cured in the apparatus box immersed in water at } \\
\text { its full height }\end{array}$ \\
\hline \multirow{3}{*}{ The samples cured in a room temperature, protected from drying } \\
\cline { 2 - 2 } & $\begin{array}{l}\text { The samples protected from drying, cured for 3 days in a room temperature, then im- } \\
\text { mersed in water to a height of } 1 \mathrm{~cm} \text { for } 1 \text { day and after that immersed to a full height } \\
\text { for 3 days }\end{array}$ \\
\hline
\end{tabular}

that were $60 \times 60 \mathrm{~mm}$ in cross section and $2.0 \mathrm{~cm}$ high. Samples were formed in the box at the water content close to optimum and compaction indexes $I_{S}=0.90,0.95$ and 1.00. During consolidation and shearing the samples were loaded with 50, 75, 100, 150, 200 and $300 \mathrm{kPa}$. The shearing velocity was $0.1 \mathrm{~mm} \cdot \mathrm{min}^{-1}$. The maximum value of shear stress obtained during the test was used in calculations.

The testes were carried out directly after samples compaction (with a shear
An attempt to use water curing outside of the apparatus box was also made, but the samples which were immersed in water directly after compaction fell apart in a few hours.

\section{RESULTS AND DISCUSSION}

\section{Physical parameters}

A silt fraction content was $78 \%$ and it dominated in the grain size distribution of the fly ash. Apart from silt there were also $19 \%$ of sand and $3 \%$ of clay (Fig. 1). According to the geotechnical 


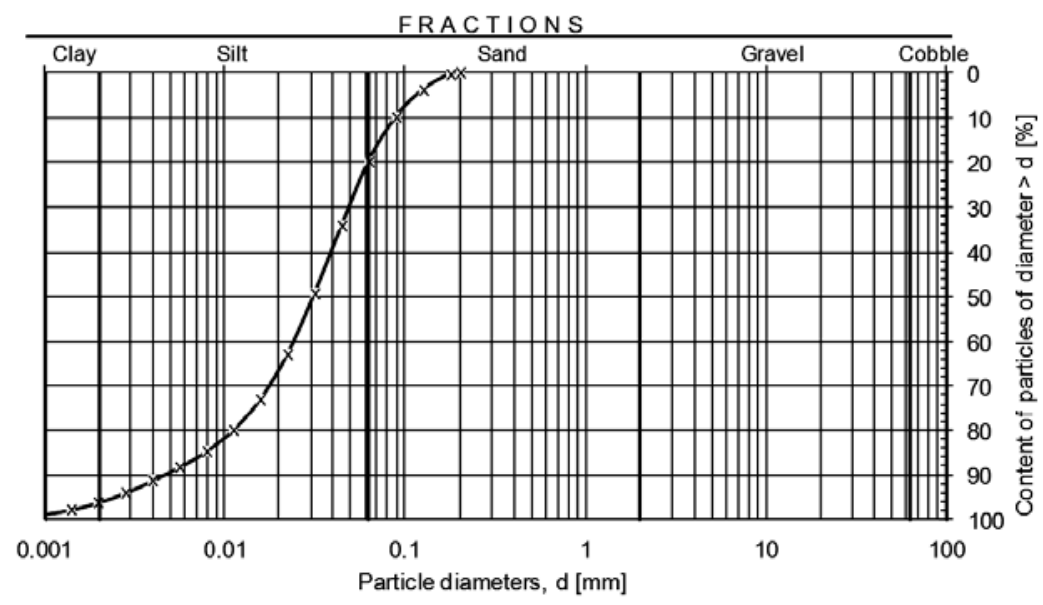

FIGURE 1. Particle size distribution curve of fluidized fly ash

nomenclature (PN-EN ISO-14688- mum value of shear stress was obtained 2:2006) the fluidized fly ash was classi- in the initial state of shearing, when the fied as sandy silt (Table 2).

The specific density was $2.75 \mathrm{~g} \cdot \mathrm{cm}^{-3}$, whereas the maximum dry density was $1.42 \mathrm{~g} \cdot \mathrm{cm}^{-3}$ at the optimum water content of $26 \%$.

\section{Shear strength}

While analyzing the changes in shear stresses during shearing it was stated that a brittle failure occurred. The maxideformation of the sample was from 1 to $3 \%$. Once the maximum values were obtained, the shear stresses most often decreased. It should be emphasized that the character of shearing was similar in case of samples tested directly after compaction (when the shearing zone was dry and when it was immersed in water as well) as well as in case of samples after air and water curing.

TABLE 2. Geotechnical characteristic of fluidized fly ash

\begin{tabular}{|l|c|}
\hline \multicolumn{1}{|c|}{ Parameter } & Value \\
\hline Fraction content $[\%]$ & \\
- sand, Sa: $2 \div 0.063 \mathrm{~mm}$ & 19 \\
- silt, $\mathrm{Si}: 0.063 \div 0.002 \mathrm{~mm}$ & 78 \\
- clay, $\mathrm{Cl}:<0.002 \mathrm{~mm}$ & 3 \\
\hline Name acc. to PN-EN ISO $14688: 2006$ & saSi \\
& (sandy silt) \\
\hline Uniformity coefficient $\mathrm{C}_{\mathrm{U}}[-]$ & 8.67 \\
\hline Coefficient of curvature $\mathrm{C}_{\mathrm{C}}[-]$ & 1.85 \\
\hline Specific density $\left[\mathrm{g} \cdot \mathrm{cm}^{-3}\right]$ & 2.75 \\
\hline Optimum moisture content o.M.c [\%] & 26.0 \\
\hline Maximum dry density $\left[\mathrm{g} \cdot \mathrm{cm}^{-3}\right]$ & 1.42 \\
\hline
\end{tabular}


The obtained shear strength is reflected in the values of the angle of internal friction and cohesion. The highest values of the angle, which increased from 47 to $48^{\circ}$ along with the increase in compaction $\left(I_{S}\right)$ from 0.90 to 1.00 , were obtained after 7 days of air curing. The highest values of cohesion, from 227 to $315 \mathrm{kPa}$, were also obtained for samples after 7 days, but with air-water curing (Table 3). On the other hand the lowest values of shear strength were obtained in case of samples tested directly after compaction. The angle of internal friction changed from 32.8 to $33.3^{\circ}$ along with the increase in compaction $\left(I_{S}\right)$ from 0.90 to 1.00 while the shear zone was not immersed in water and cohesion was from 7 to $23 \mathrm{kPa}$ and these values were determined while the shear zone was immersed in water.
While analyzing the influence of compaction it can be stated that the angle of internal friction increased in a small range, whereas in case of cohesion there was a significant increase along with the increase in compaction $\left(I_{S}\right)$ from 0.90 to 1.00 (Fig. 2). Testes carried out directly after compaction showed an increase in the angle of internal friction by $0.5^{\circ}$ in case of air curing and by $1.3^{\circ}$ in case of water curing, whereas cohesion values increased by over $23 \mathrm{kPa}$ in case of air curing and $11 \mathrm{kPa}$ in case of water curing. Testes that were carried out after 0.5 hours of air and water curing showed an increase of the angle of internal friction by almost $1^{\circ}$ and in case of cohesion it was similarly - almost $23 \mathrm{kPa}$ (air curing) or $11 \mathrm{kPa}$ (water curing). Results for samples tested after 16 hours of air

TABLE 3. Values of shear strength parameters of the fluidized fly ash (Gruchot 2014, Marcinów 2014)

\begin{tabular}{|c|c|c|c|c|c|}
\hline \multicolumn{2}{|c|}{ Curing } & \multirow{2}{*}{ Parameter } & \multicolumn{3}{|c|}{ Compaction index [-] } \\
\hline Type & time & & 0.90 & 0.95 & 1.00 \\
\hline \multirow{8}{*}{ Air } & \multirow{2}{*}{0} & angle of internal friction $(\phi)\left[^{\circ}\right]$ & 32.8 & 33.0 & 33.3 \\
\hline & & cohesion $(\mathrm{c})[\mathrm{kPa}]$ & 63.5 & 67.0 & 87.0 \\
\hline & \multirow{2}{*}{$0.5 \mathrm{~h}$} & angle of internal friction $(\phi)\left[^{\circ}\right]$ & 36.6 & 37.0 & 37.5 \\
\hline & & cohesion $(\mathrm{c})[\mathrm{kPa}]$ & 26.0 & 32.4 & 48.8 \\
\hline & \multirow{2}{*}{$16 \mathrm{~h}$} & angle of internal friction $(\phi)\left[^{\circ}\right]$ & 38.5 & 39.9 & 42.1 \\
\hline & & cohesion $(\mathrm{c})[\mathrm{kPa}]$ & 24.5 & 31.2 & 57.9 \\
\hline & \multirow{2}{*}{7 days } & angle of internal friction $(\phi)\left[^{\circ}\right]$ & 47.4 & 47.7 & 48.4 \\
\hline & & cohesion $(\mathrm{c})[\mathrm{kPa}]$ & 221.4 & 243.0 & 314.3 \\
\hline \multirow{6}{*}{ Water } & \multirow{2}{*}{0} & angle of internal friction $(\phi)\left[^{\circ}\right]$ & 33.9 & 34.4 & 35.3 \\
\hline & & cohesion $(\mathrm{c})[\mathrm{kPa}]$ & 7.0 & 9.4 & 23.1 \\
\hline & \multirow{2}{*}{$0.5 \mathrm{~h}$} & angle of internal friction $(\phi)\left[^{\circ}\right]$ & 31.4 & 31.6 & 32.3 \\
\hline & & cohesion $(\mathrm{c})[\mathrm{kPa}]$ & 39.8 & 41.0 & 51.6 \\
\hline & \multirow{2}{*}{$16 \mathrm{~h}$} & angle of internal friction $(\phi)\left[^{\circ}\right]$ & 34.5 & 34.8 & 36.2 \\
\hline & & cohesion $(\mathrm{c})[\mathrm{kPa}]$ & 68.7 & 64.7 & 90.4 \\
\hline \multirow{2}{*}{ Air-water } & \multirow{2}{*}{7 days } & angle of internal friction $(\phi)\left[^{\circ}\right]$ & 34.6 & 35.7 & 40.0 \\
\hline & & cohesion $(\mathrm{c})[\mathrm{kPa}]$ & 234.2 & 261.3 & 337.8 \\
\hline
\end{tabular}


a

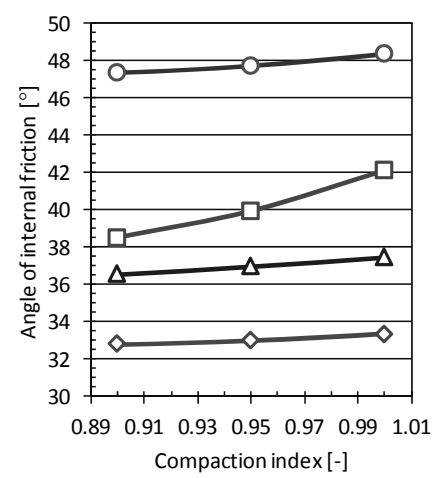

b

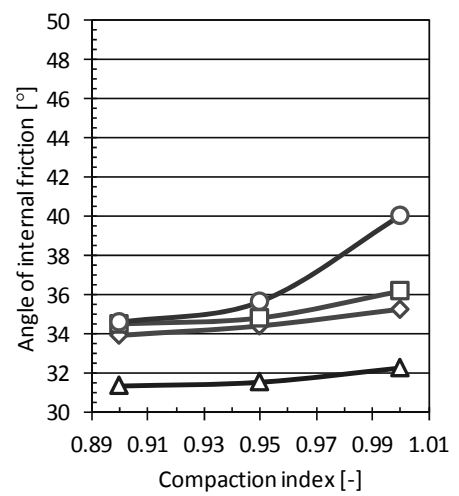

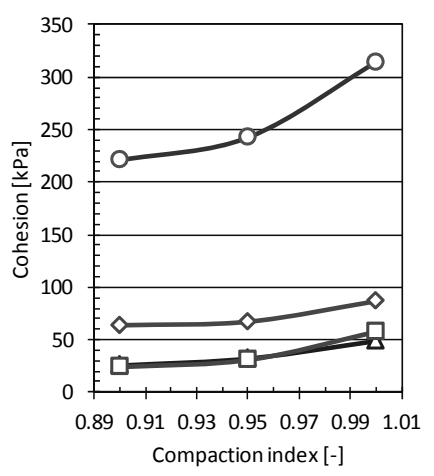

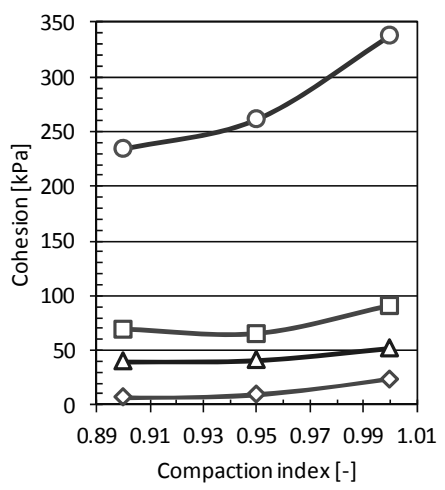

$\precsim$ after compaction $\triangle$ after 0.5 h curing

$\square$-after $16 \mathrm{~h}$ curing $\quad-$-after 7 days curing

FIGURE 2. Influence of compaction on shear strength parameters: $a$ - air curing; $b$ - water and air-water curing

and water curing showed an increase in the angle of internal friction by 4 and $2^{\circ}$ adequately, and in cohesion by a little over $33 \mathrm{kPa}$ and close to $22 \mathrm{kPa}$.

An increase in compaction $\left(I_{S}\right)$ from 0.90 to 1.00 for samples after 7 days of air curing caused an increase of the angle of internal friction by $1^{\circ}$ and of cohesion by almost $93 \mathrm{kPa}$. In case of 7 days of air and water curing the increase in the value of the angle was close to $5.5^{\circ}$ and in case of cohesion it was almost $104 \mathrm{kPa}$.

An analysis of influence of the air curing time on the shear strength param- eters showed that there was an increase of the angle of internal friction on average by $4^{\circ}$ after 0.5 hours and by $7^{\circ}$ after 16 hours at all compactions in relation to the tests carried out directly after samples compaction (Fig. 3a). In case of cohesion and the same curing times there was a decrease of value, on average by 37 and $35 \mathrm{kPa}$. After 7 days of air curing the angle of internal friction increased by about $15^{\circ}$ and in case of cohesion the value increased by $160 \mathrm{kPa}$ at $I_{S}=0.90$ and by $227 \mathrm{kPa}$ at $I_{S}=1.00$. 
a

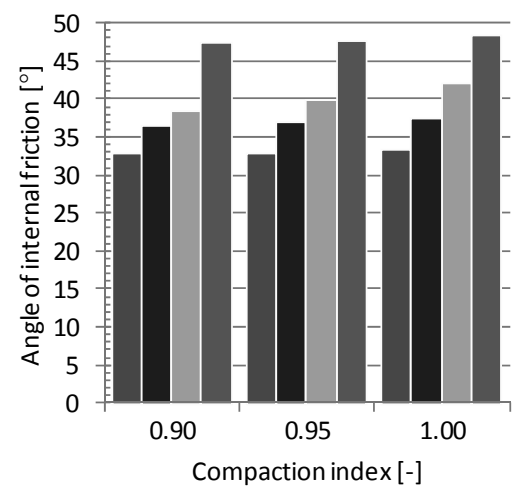

b

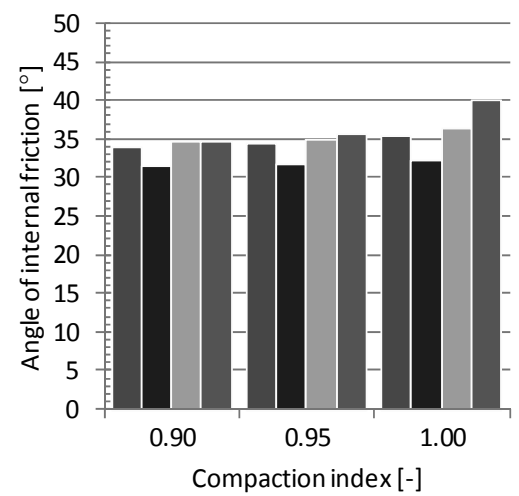

$\square$ after compaction $\square$ after $0.5 \mathrm{~h}$ curing
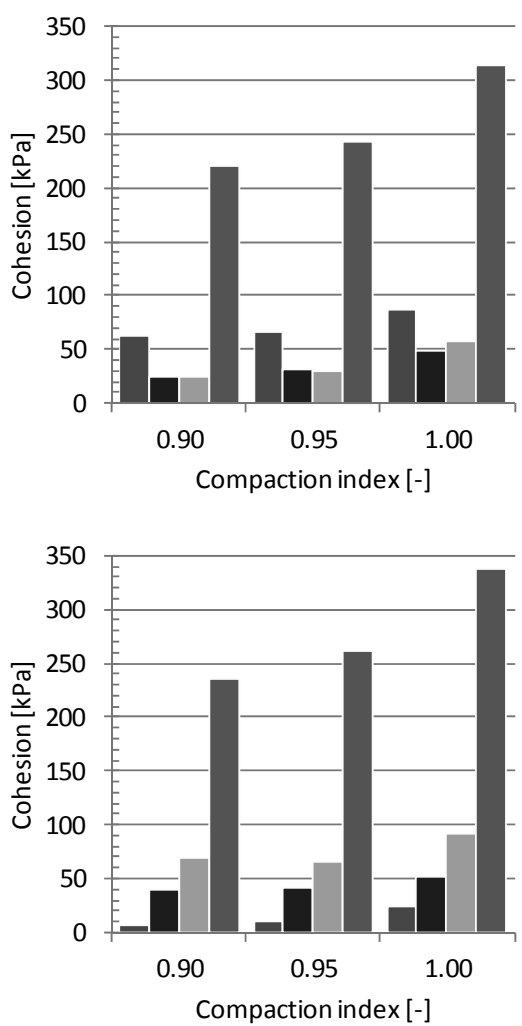

$\square$ after 16 h curing $\square$ after 7 days curing

FIGURE 3. Influence of curing time on shear strength parameters: $a$ - air curing; $b$ - water and air-water curing

The 0.5 hours water curing caused insignificant (by only $3^{\circ}$ ) decrease of the angle of internal friction and increase of cohesion by about $31 \mathrm{kPa}$ (Fig. 3b). Extending the curing time up to 16 hours caused a small increase of: the angle by about $1^{\circ}$ and the cohesion by $55 \mathrm{kPa}$ at $I_{S}=0.95$ and by $67 \mathrm{kPa}$ at $I_{S}=1.00$. After 7 days of air and water curing an increase in the value of the angle of internal friction was also obtained - by about $1^{\circ}$ at $I_{S}=0.90$ and 0.95 and almost $5^{\circ}$ at $I_{S}=1.00$. Whereas the increase of cohe- sion was from $227 \mathrm{kPa}$ at $I_{S}=0.90$ up to $315 \mathrm{kPa}$ at $I_{S}=1.00$.

To sum up, it should be indicated that the high values of shear strength of the tested fluidized fly ash are the result of pozzolanic reactions that occur as a result of increased concentration of calcium and sulfur oxides in relation to ashes form conventional furnaces. Analysis of chemical constitution indicates that hard coal combustion in fluidized-bed furnaces produces from 4 to $20 \%$ of unreacted calcium in the form of oxides and 
bound calcium in the form of anhydrite (Wisła-Wlash et al. 1999). The influence of an increased content of the active calcium oxide was the most noticeable after 7 days of air and air-water curing. Subsequently, further tests on shear strength of the fluidized fly ash after different types and times of curing were carried out. Their results were presented in a paper, which has not been published yet (Gruchot et al. 2014).

\section{CONCLUSIONS}

Based on the analysis of the results of shear strength tests on the fluidized fly ash from "Połaniec" Power Plant it was stated that:

1. Shear strength parameters of the tested fluidized fly ash were high, which was mostly the result of pozzolanic reactions that occurred during the curing time.

2. The increase in compaction $\left(I_{S}\right)$ from 0.90 to 1.00 resulted in an insignificant increase of the angle of internal friction and a quite significant increase of cohesion.

3. Type of curing had a great influence on the shear strength parameters. The highest values of the angle of internal friction were obtained after air curing, the lowest - after water curing. A reverse relation was noticed for cohesion - the highest values were determined after water curing, whereas the lowest after air curing.

4. Curing time had a crucial influence on the shear strength parameters. Al- though it should be emphasized that the biggest changes were noticed in case of cohesion. Extending curing time to 7 days resulted in an increase of cohesion - it was 3.5 times higher after air curing at all compaction indexes and 34 times higher after water curing at $I_{S}=0.90$. In case of the angle of internal friction such significant changes were not noticed.

Different additions, such as biomass, are combusted in fluidized-bed furnaces with hard coal and thus qualitative and chemical compositions of the ash can change in a wide range. Therefore a detailed control of the quality of fluidized fly ash should be carried out before it is used in earthworks.

\section{Acknowledgments}

The results of research carried out under the theme DS-3322/KIWiG/2014 were financed with a grant for science conferred by The Ministry of Science and Higher Education.

\section{REFERENCES}

BIELIŃSKA E.J., BARAN S., STANKOWSKI S. 2009: Ocena przydatności popiołów fluidalnych z węgla kamiennego do celów rolniczych. [Assessment concerning usability of fluidal ashes from hard coal for agricultural purposes]. Inżynieria Rolnicza 6 (115), 7-15 [Engl. summ.].

BRZOZOWSKI P. 2011: Możliwości wykorzystania popiołów lotnych ze spalania w kotłach fluidalnych do betonów układanych pod woda. [Examination of fly ash from fluidized bed boilers in underwater concrete], Budownictwo i Inżynieria Środowiska 2, 5-11 [Engl. summ.]. 
Dz.U. z 2006 r. nr 49, poz. 356. Rozporządzenie Ministra Środowiska z 21 marca 2006 roku w sprawie odzysku lub unieszkodliwiania odpadów poza instalacjami i urządzeniami. [Journal of Laws 2006, no 49, item 356. Regulation of the Minister of Environment from 21st March 2006 on recovery or disposal of waste beyond installations and devices].

FILIPIAK J. 2011: Popiół lotny w budownictwie. Badania wytrzymałościowe gruntów stabilizowanych mieszanką popiołowo-cementową. [Fly ash in construction industry. Strength tests of soil stabilized with mixture of ash and cement]. Rocznik Ochrona Środowiska (Annual Set of Environment Protection) 13, 1043-1054 [Engl. summ.].

FILIPIAK J. 2013: Wykorzystanie ubocznych produktów spalania jako stabilizatora do wzmacniania gruntów organicznych. [Application of Combustion By-products as a Stabilizer for Organic Soils]. Rocznik Ochrona Środowiska (Annual Set of Environment Protection) 15, 1153-1163 [Engl. summ.].

GAWLICKI M., WONS W. 2013: Właściwości fizykochemiczne popiołów lotnych z kotłów fluidalnych i ich wpływ na wybrane cechy użytkowe mieszanek drogowych. [Physical and chemical properties of FBC fly ash and its influence on selected properties of road mixtures]. Prace Instytutu Ceramiki i Materiałów Budowlanych 12, 18-27 [Engl. summ.].

GIERGICZNY Z. 2006: Rola popiołów lotnych wapniowych i krzemionkowych w kształtowaniu właściwości współczesnych spoiw budowlanych i tworzyw cementowych. Wydawnictwo Politechniki Krakowskiej, monografia $\mathrm{nr} 325$.

GRUCHOT A. 2014: Charakterystyka geotechniczna popiołów fluidalnych $\mathrm{z}$ Elektrowni „Połaniec”. Katedra Inżynierii Wodnej i Geotechniki Uniwersytetu Rolniczego w Krakowie. MS.

GRUCHOT A., ZYDROŃ T., GAŁOWICZ E. 2014: Parametry wytrzymałościowe fluidalnego popiołu lotnego z Elektrowni „Połaniec". [Mechanical properties of fluidized fly ash from Power Station "Połaniec"]. Katedra Inżynierii Wodnej i Geotechniki Uniwersytetu Rolniczego w Krakowie. MS [Engl. summ.].
HYCNAR J. 2006: Paleniska fluidalne przykładem racjonalnego rozwiązania problemów odpadów. [Fluidized beds - an example of rational solution of waste problems]. Polityka Energetyczna 9, 365-376 [Engl. summ.].

IWANEK P., JELONEK I., MIRKOWSKI Z. 2008: Wstępne badania popiołów $\mathrm{z}$ kotła fluidalnego $\mathrm{w}$ aspekcie ich zagospodarowania. [preliminary research on fly ash from the fluidal boiler in the context of its development]. Gospodarka Surowcami Mineralnymi 24 (4/4), 91-104 [Engl. summ.].

KABAŁA J., BRZOZOWSKI B., ROSZCZYNIALSKI W., MAŁOLEPSZY J. 2006: Właściwości i zastosowanie ubocznych produktów spalania węgla w kotłach fluidalnych. Materiaty Konferencji „Popioły $z$ energetyki", Kraków, 121-140.

KODA E., OSIŃSKI P. 2011: Slope erosion control with the use of fly-ash and sewage sludge. Annals Warsaw University of Life Sciences SGGW, Land Reclamation 43 (2), 101-111.

KUBISSA W., WILIŃSKA I., PAŁUBA M. 2013: Badania właściwości betonów cementowych wykonanych $\mathrm{z}$ udziałem odpadów przemysłowych. Konstrukcje -Elementy - Materiaty 1, 35-39.

MARCINÓW K. 2014: Wytrzymałość na ścinanie fluidalnych popiołów lotnych. [Shear strength of fluidized fly ash]. Praca magisterska, Katedra Inżynierii Wodnej i Geotechniki Uniwersytetu Rolniczego w Krakowie, maszynopis.

NIESLER J. 2001. Rozwój palenisk fluidalnych $\mathrm{w}$ energetyce. [Development of fluidised bed furnaces in the power industry]. Piece Przemystowe \& Kotty 4, 33-36 [Engl. summ.].

PN-EN 197-1:2012. Cement. Część 1. Skład, wymagania i kryteria zgodności dotyczące cementów powszechnego użytku. Polski Komitet Normalizacyjny, Warszawa.

PN-EN-ISO-14688-2:2006. Badania geotechniczne. Oznaczenia i klasyfikowanie gruntów. Część 2: Zasady klasyfikacji. Polski Komitet Normalizacyjny, Warszawa.

POMYKAŁA R., KĘPYS W., ŁYKO P. 2013: Wpływ temperatury oraz dodatku cementu na czas wiązania zawiesin popiołowo-wodnych. [Effect of temperature and cement additive on setting time of fly ash-water suspensions]. Rocznik Ochrona Środowiska (Annual Set The Environment Protection) 15, 1818-1833 [Engl. summ.]. 
ROSZCZYNIALSKI W., GAWLICKI M. 2004: Uboczne produkty spalania jako składniki spoiw mineralnych. [Combustion by-products as mineral binders components]. Materiaty Szkoty Gospodarki Odpadami, Rytro.

SYBILSKI D., KRASZEWSKI C. 2004: Ocena i badania wybranych odpadów przemysłowych do wykorzystania w konstrukcjach drogowych. Instytut Badawczy Dróg i Mostów w Warszawie. MS.

WISŁA-WALSH E., MIĘSO R., SIKORA W. 1999: Badania procesu grudkowania popiołów lotnych i wybrane własności fizykochemiczne otrzymanych granulatów. [Research into fly ash agglomeration process and physicochemical properties of pellets]. Polskie Towarzystwo Mineralogiczne - Prace Specjalne 13, 99-119.

ZAWISZA E., GRUCHOT A.T. 2008: Wpływ stabilizacji cementem lub silmentem na wytrzymałość i mrozoodporność gruntu pylastego. [Influence of stabilization with cement or silment on the strength and frost resistance of silty soil]. Górnictwo i Geoinżynieria 32 (1), 371-379 [Engl. summ.].

ZAWISZA E., KŁĘK K. 2006: Stabilizacja popiołów spoiwami „Silment” w drogownictwie. [Stabilization of Ashes with "Silment" Binder in Road Engineering]. Drogownictwo 12, 396-401 [Engl. summ.].
Streszczenie: Wplyw czasu pielęgnacji na wytrzymałość na ścinanie fluidalnych popiołów lotnych. $\mathrm{W}$ pracy przedstawiono wyniki badań wpływu zagęszczenia oraz czasu pielęgnacji powietrznej i wodnej na kąt tarcia wewnętrznego i spójność fluidalnego popiołu lotnego ze zsypu Elektrowni „Połaniec”. Stwierdzono, że wzrost zagęszczenia spowodował niewielkie zwiększenie wartości parametrów wytrzymałości na ścinanie. Rodzaj pielęgnacji i jej czas miały natomiast decydujący wpływ na wartości kąta tarcia wewnętrznego i spójność. Największe wartości kąta tarcia wewnętrznego uzyskano przy pielęgnacji powietrznej, a najmniejsze przy pielęgnacji wodnej przy odwrotnej zależności dla spójności. Wzrost czasu pielęgnacji spowodował kilkukrotny wzrost spójności, przy niewielkich zmianach kąta tarcia wewnętrznego.

Słowa kluczowe: wytrzymałość na ścinanie, fluidalny popiół lotny, utylizacja

MS. received May 2015

\author{
Author's address: \\ Gruchot Andrzej \\ Katedra Inżynierii Wodnej i Geotechniki \\ Uniwersytet Rolniczy w Krakowie \\ al. Mickiewicza 24/28, 30-059 Kraków \\ Poland \\ e-mail: rmgrucho@cyf-kr.edu.pl
}

